\title{
Peculiarities of Sputum Microbiocenosis among Occupational COPD Patients with Different Clinical Phenotypes and Comorbidities
}

\author{
Vasily D. Fedotov ${ }^{1,2 *}$, Natalya V. Mokeeva ${ }^{1}$, Irina S. Dobrotina ${ }^{2}$, Anastasia N. Novikova ${ }^{2}$, \\ Viktoria E. Kovalenko ${ }^{2}$ and Aleksandra A. Kalınına ${ }^{2}$
}

${ }^{I}$ Federal Budget Scientific Institution, Hygiene and Occupational Pathology Research Institute of Nizhny Novgorod, Federal Service for the Oversight of Consumer Protection and Welfare, Russian Federation

${ }^{2}$ Federal State Budgetary Educational Institution of Higher Education, Privolzhsky Research Medical University of the Ministry of Health of the Russian Federation

*Corresponding author

\begin{tabular}{|c|c|}
\hline & A B S T RA C T \\
\hline $\begin{array}{l}\text { Ke y w o r d s } \\
\text { Occupational } \\
\text { COPD, Microbiom, } \\
\text { Chronic bronchitis, } \\
\text { Diabetes mellitus }\end{array}$ & \multirow{3}{*}{$\begin{array}{l}\text { The aim of the research was to study the microbial landscape of sputum of patients with } \\
\text { occupational COPD with different clinical phenotypes and comorbidity. The objective of } \\
\text { the study was } 374 \text { patients with chronic occupational respiratory pathology. A comparative } \\
\text { analysis of sputum microbiocenosis was performed in all the patients of the groups (on the } \\
\text { whole, there were } 616 \text { samples of sputum gathered from } 374 \text { patients). Microorganisms } \\
\text { could be detected statistically more often in patients with the combination of COPD and } \\
\text { DM (p<0.001). A bacterial monoculture statistically more often was detected in patients } \\
\text { with chronic non obstructive bronchitis and COPD - non exacebrator groups ( }<0.001 \text { ). } \\
\text { Microbial associations were detected significantly more often among the patients who had } \\
\text { COPD-Asthma overlap and DM II (p<0.001). The conspicuous quantitative and qualitative } \\
\text { changes of respiratory tract microbiom of patients with occupational COPD are observed } \\
\text { only if they have associated DM II. }\end{array}$} \\
\hline Article Info & \\
\hline $\begin{array}{l}\text { Accepted: } \\
\text { 24 November } 2018 \\
\text { Available Online: } \\
10 \text { December } 2018\end{array}$ & \\
\hline
\end{tabular}

\section{Introduction}

The chronic obstructive pulmonary disease (COPD) appears to be one of the acutest medical and social problems of contemporary medicine. This pathology comes forward among causes of premature mortality of patients with lung diseases (1). COPD is characterized by a persistent inflammatory process in the pulmonary tissue and slowly progressive reduction of the expiratory flow (2).
It is well known that one of the important peculiarities of the course of this disease is the sequence of exacerbations and periods of stability. According to the data of research literature frequency of exacerbations in most cases correlates with disease severity, and one of the main causes of exacerbations is activation of opportunistic pathogenic bacteria of bronchial mucus (3). As reported by established investigators if COPD is not severe, the dominant etiological agents are 
Haemophilus influenza, Streptococcus pneumoniae, Moraxella catarralis, etc. (4). Alongside this fact, with severe forms of COPD, there are Pseudomonas aeruginosa and some other commensal microbiota prevailing $(5,6)$.

Moreover, a dysbiosis in bacterial diversity can lead to infection, inducing epithelial injury and pro-inflammatory reactions (7).

Considering the fact that the conventional therapy of COPD exacerbations includes the administration of broncholytic, systemic glucocorticoids combined with antibiotics, it increases the risk of getting a secondary bacterial infection (8).

However, at the present time, the evidence of microflora characteristics of patients with occupational COPD during a stable phase, which is aggravated by comorbid pathology, is insufficient.

The aim of the research was to study the microbial landscape of sputum of patients with occupational COPD with different clinical phenotypes and comorbidity (diabetes mellitus type 2).

\section{Materials and Methods}

This study followed the ethical criteria recommended by the Resolution N 248 of 14.08.1998 of Ministry of Health of the Russian Federation. All patients received an explanation about the study and gave consent by participating in the study.

The research has been conducted at the premises of therapeutic clinic of the Federal budget scientific institution "Nizhny Novgorod research institute for hygiene and occupational pathology", Rospotrebnadzor, Nizhny Novgorod. The object of the study were factory workers of metallurgical and mechanical engineering industries $(270$ men and 104 women with work record 23.5 \pm 7.4 years and $20.2 \pm 4.8$ years respectively), who were systematically exposed to siliceous and metal dust in concentrations, exceeding the allowable limits (more than $10 \mathrm{mg} / \mathrm{m}^{3}$, with maximum allowable limits $2.0 \mathrm{mg} / \mathrm{m}^{3}$ ). All of the patients were under case follow-up.

The examined patients were divided into 4 groups, matched in age and gender. In the first group, there were 66 patients (53 men and 13 women) aged 55.6 \pm 1.9 with occupational nonobstructive chronic bronchitis.

In the second group, there were 133 patients (115 men and 18 women) with non-severe COPD non-exacebrator phenotype. The age of the patients in this group was $55.7 \pm 1.9$ years.

The third group consisted of 110 patients (67 men and 43 women, aged 56.4 \pm 2.1 years) who had the asthma-COPD overlap (ACO) asthma during remission.

The fourth group included 65 patients ( 35 men and 30 women, aged 56.1 \pm 2.0 ) with nonsevere stable COPD and associated diabetes mellitus (DM) of the $2^{\text {nd }}$ type. Due to DM, the patients received adequate oral antidiabetic therapy; they had no clinically significant micro- and macroangiopathy.

The chronicity of non-obstructive bronchitis and COPD in all of the groups ranged from 6 to 12 years.

In order to increase the accurateness of the research, sputum culture was performed twice during hospitalization (on the whole, there were 616 samples of sputum gathered from 374 patients).

As a part of the study, a comparative analysis of sputum microbiocenosis was performed in all the patients of the groups mentioned above. 
Freely coughed-up sputum served as the material for bacteriological investigation. Collecting of samples was carried out in accordance with guidelines of the Order of the Ministry of Health of the USSR of 22.04.1985 \#535 (9). All samples were stained according to Gram, followed by a bacterioscopy to evaluate the quality of the sample and to determine the morphotype of the bacteria. The samples that met Murrey-Washington criteria ( $<10$ of epithelial cells and $>25$ of leucocytes per field x100) (8) were tested for bacterial culture.

In order to detect aerobic and facultative anaerobic microorganisms inoculation of selective and differential diagnostic nutrient media was conducted: blood agar, chocolate agar, Enterococcus agar, Endo agar, BairdParker agar. For isolation of Candida, the yeast-like fungi, there was Sabouraud agar and chromogenic medium used.

The plates with blood and chocolate agar were being incubated at $+35^{\circ} \mathrm{C}$ in the atmosphere with an increased concentration of carbon dioxide during 20-24 hours. The plates with selective medium were being incubated at $37^{\circ}$ $\mathrm{C}$ during 24-48 hours. The fungi were cultured at $+28-30^{\circ} \mathrm{C}$ for four days.

Identification of aerobic and facultative anaerobic microorganisms was made with the help of gold standard technique and test systems: set of instruments for diagnostics ("Microgen"), biochemical plates ("Diagnostic systems”), Auxacolor (“Bio-Rad”).

The statistical data processing was performed with the help of Microsoft Excel software suite. When comparing the groups, a twotailed Student's test was used.

\section{Results and Discussion}

During the evaluation of microbiocenosis of sputum several groups of gram-negative bacteria (microorganisms of Enterobacteriacae family: E. coli, Klebsiella spp, Enterobacter spp etc.; non-fermentative gram-negative microorganisms: Ps. aeruginosa, Acinetobacter spp, Alcaligenes spp, etc.), gram-positive cocci (streptococci of Pyogenic group, Staphylococcus aureus, Enterococcus spp) and fungi were detected. The results of the microbiological research among the patients of all the four groups showed the absence of growth in $23.9 \%$ of the sputum samples. In the first three groups microorganisms could be detected in $71.6 \%$, $78.4 \%$, and $67.8 \%$ respectively and by the combination of COPD and DM - statistically more often (in 91.7\%) $(\mathrm{p}<0.001)$. It should be mentioned that the particular results were obtained during the period of absence of COPD exacerbation amid follow-up examinations of the patients. The significant difference of this rate in the fourth group is presumably connected with the negative influence of comorbid DM.

There was a bacterial monoculture detected in $39.1 \%$ of the positive sputum samples, notably in the first and the second groups it was detected statistically more often, in $41.9 \%$ and $43.2 \%$ respectively, $(\mathrm{p} 1-2=1.0)$. Microbial associations were detected significantly more often among the patients who had COPDAsthma overlap (ACO) and DM II. For example, in the third group (ACO) monocolonies were obtained only in $37.1 \%$ (p1-3 $<0.001$, p2-3<0.001), and with COPD and DM II (the fourth group) they were obtained only in $31.3 \%$ in positive microbiological inoculation ( $\mathrm{p} 1-4<0.001)$. The mono-cultures were mostly implemented by Enterobacteriaceae (28.4\%), Candida fungi $(43.0 \%)$ and beta-hemolytic streptococcus (26.6\%). Notwithstanding the absence of patients with severe and extremely severe COPD in the patient samples, $S$. aureus was inoculated in $17.3 \%$ and Ps. aeruginosa - in $7.3 \%$ (Table 1). 
Frequently enough there were associations of two, three and more microorganisms detected (in $36.9 \%$ of the positive sputum samples). In the first three groups of the patients, the frequency of detection of microbial associations was not significantly different and amounted to $29.7 \%, 35.3 \%$, and $30.7 \%$, respectively. With COPD and DM II as a comorbid, this rate was statistically much more significant $-59.4 \%(\mathrm{p}<0.001)$. The most common participants of associations were gram-positive coccus (beta-hemolytic streptococcus of the A-group, S. aureus and Staphylococcus spp, Enterococcus spp.), Candida fungi and gram-negative bacteria ( $E$. coli, Klebsiella spp, Enterobacter spp, Ps. aeruginosa).
As it follows from the table data, the frequency of detection of microorganisms from the sputum samples of the patients of the first three groups did not have a significant difference. Only the combination of COPD and DM of the $2^{\text {nd }}$ type creates suitable conditions for reproduction of microorganisms in the respiratory tract, which is demonstrated by the statistically significant increase of microbial associations' occurrence. In this research, there was no Haemophilus influenzae predominance exposed which according to the literature data is the main cause of bacterial exacerbations (3).

Table.1 Prevalence of microorganisms in the sputum samples of the examined patients, $(\mathrm{M} \pm \mathrm{m})$

\begin{tabular}{|c|c|c|c|c|}
\hline Microbial flora & $\begin{array}{l}\text { Group } \\
\mathrm{n}=74\end{array}$ & $\begin{array}{l}\text { Group } \\
\mathrm{n}=241\end{array}$ & $\begin{array}{l}\text { Group } \\
n=205\end{array}$ & $\begin{array}{l}\text { Group } \\
n=96\end{array}$ \\
\hline $\begin{array}{l}\text { Gram-positive } \\
\text { coccus, } \\
\text { including: }\end{array}$ & $45.9 \pm 5.8$ & $\begin{array}{l}37.8 \% \pm 3.1 \\
\mathrm{t}_{1-2}=1.2\end{array}$ & $\begin{array}{l}36.1 \% \pm 3.3 \\
\mathrm{t}_{1-3}=1.5\end{array}$ & $\begin{array}{l}75.0 \% \pm 4.4 \\
t_{1-4}=2.7\end{array}$ \\
\hline $\begin{array}{l}\text { Streptococcus } \\
\text { of the beta } \\
\text { group }\left(1 * 10^{7}\right. \\
\text { CFU*) }\end{array}$ & $20.3 \% \pm 4.7$ & $\begin{array}{l}25.7 \% \pm 2.8 \\
t_{1-2}=0.98\end{array}$ & $\begin{array}{l}22.9 \% \pm 2.9 \\
\mathrm{t}_{1-3}=0.5\end{array}$ & $\begin{array}{l}41.6 \% \pm 5.0 \\
t_{1-4}=1.1\end{array}$ \\
\hline $\begin{array}{l}\text { S. } \quad \text { aureus } \\
\left(0.4 * 10^{7} \mathrm{CFU}\right)\end{array}$ & $25.7 \% \pm 5.1$ & $\begin{array}{l}12.1 \pm 2.1 \\
t_{1-2}=2.5\end{array}$ & $\begin{array}{l}13.2 \% \pm 2.4 \\
\mathrm{t}_{1-2}=2.2\end{array}$ & $\begin{array}{l}33.3 \% \pm 4.8 \\
t_{1-2}=1.1\end{array}$ \\
\hline $\begin{array}{l}\text { Gram-negative } \\
\text { bacteria, } \\
\text { including: }\end{array}$ & $33.8 \% \pm 5.5$ & $\begin{array}{l}45.3 \% \pm 3.2 \\
\mathrm{t}_{1-2}=1.8\end{array}$ & $\begin{array}{l}26.3 \% \pm 3.1 \\
t_{1-3}=1.2\end{array}$ & $\begin{array}{l}46.9 \% \pm 5.1 \\
t_{1-4}=1.7\end{array}$ \\
\hline $\begin{array}{l}\text { Fam. } \\
\text { Enterobacter } \\
\left(1 * 10^{7} \mathrm{CFU}\right)\end{array}$ & $28.4 \% \pm 5.2$ & $\begin{array}{l}34.4 \% \pm 3.1 \\
t_{1-2}=1.0\end{array}$ & $\begin{array}{l}18.5 \% \pm 2.7 \\
\mathrm{t}_{1-3}=1.7\end{array}$ & $\begin{array}{l}34.4 \% \pm 4.8 \\
t_{1-4}=0.84\end{array}$ \\
\hline $\begin{array}{l}\text { Non- } \\
\text { fermentative } \\
\text { gram-negative } \\
\text { microorganisms } \\
\left(0.02 * 10^{7} \mathrm{CFU}\right)\end{array}$ & $5.4 \% \pm 2.6$ & $5,4 \% \pm 1,5$ & $\begin{array}{l}7,8 \% \pm 1,9 \\
\mathrm{t}_{1-3}=0,75\end{array}$ & $\begin{array}{l}12.5 \% \pm 3.4 \\
t_{1-4}=1.7\end{array}$ \\
\hline $\begin{array}{l}\text { Candida fungi } \\
\left(1 * 10^{3} \mathrm{CFU}\right)\end{array}$ & $33.8 \% \pm 5.5$ & $\begin{array}{l}41.9 \% \pm 3.2 \\
t_{1-2}=1.3\end{array}$ & $\begin{array}{l}43.4 \% \pm 3.5 \\
\mathrm{t}_{1-3}=1.5\end{array}$ & $\begin{array}{l}52.1 \% \pm 5.1 \\
t_{1-4}=2.4\end{array}$ \\
\hline
\end{tabular}

* Colony forming unit 
The frequent detection of Candida fungi in the sputum culture in the diagnostic titer in all of the four groups can be esteemed as a consequence of a regular antibacterial and hormonal therapy, while hyperglycemia of the patients with COPD and DM of the $2^{\text {nd }}$ type contributed to the active reproduction of the fungi.

C. albicans prevailed among the Candida fungi in all of the groups $(91.0 \%)$. As a rule, other fungal species which were observed occurred in an association with it (C. krusei, C. kefyr, S. cerevisiae) and only three patients had C. tropicalis (1) and C. krusei (2) in monoculture.

In conclusion chronic inflammation in bronchi contributes to their contamination notwithstanding the presence or absence of bronchial obstruction.

There was no difference in contamination severity of the respiratory tract and detection frequency of microbial associations of the patients with occupational non-obstructive bronchitis and occupational COPD.

Occupational COPD in comparison with occupational chronic non-obstructive bronchitis had a less amount of $S$. aureus detected in the sputum samples.

The conspicuous quantitative and qualitative changes of respiratory tract microbiocenosis of patients with occupational COPD are observed only if they have associated DM of the $2^{\text {nd }}$ type. On the one part, this is conditioned by the change of immunoresponsiveness which it typical for diabetes mellitus, on the other part, by the hyperglycemia which supplies ideal conditions for active microbial growth.

The detection of Candida fungi in case of chronic bronchitis and COPD shows additionally the necessity of a strong antibacterial therapy, exclusion for selftreatment and unsupervised administration of antibacterial therapy.

\section{Funding}

The authors report that there was no funding source for the work that resulted in the article or the preparation of the article.

\section{Institution and ethics approval and informed consent}

This study followed the ethical criteria recommended by the Resolution N 248 of 14.08.1998 of Ministry of Health of the Russian Federation. All patients received an explanation about the study and gave consent by participating in the study.

\section{References}

1. Global Initiative for Chronic Obstructive Lung Disease (GOLD) Global strategy for diagnosis, management, and prevention of COPD. 2018. (Electronic resource). Available from: http://www.goldcopd.org/ (Accessed June 5, 2018).

2. Ozol, D, H Karamanli, S Uysal, M R Yiğitoğlu, Z Yildirim. Airway inflammation and tiotropium treatment in stable COPD patients. Turk J Med Sci 2014; 44: 804-808.

3. Boixeda R, Rabella N, Sauca G, Delgado M, Martínez-Costa X, Mauri M, Vicente V, Palomera E, Serra-Prat M, Capdevila JA. Microbiological study of patients hospitalized for acute exacerbation of chronic obstructive pulmonary disease (AE-COPD) and the usefulness of analytical and clinical parameters in its identification (VIRAE study). Int J Chron Obstruct Pulmon Dis. 2012; 7: 327-35.

4. Han MK, Huang YJ, Lipuma JJ, Boushey 
HA, Boucher RC, Cookson WO, Curtis JL, Erb-Downward J, Lynch SV, Sethi S, Toews GB, Young VB, Wolfgang MC, Huffnagle GB, Martinez FJ. Significance of the microbiome in obstructive lung disease. Thorax. 2012 May; 67(5): 456-63.

5. Garcia-Nuñez M, Millares L, Pomares X, Ferrari R, Pérez-Brocal V, Gallego M, Espasa M, Moya A, Monsó E. Severity-related changes of bronchial microbiome in chronic obstructive pulmonary disease. J Clin Microbiol. 2014 Dec; 52(12): 4217-23.

6. Hillas G, Perlikos F, Tsiligianni I, Tzanakis $\mathrm{N}$. Managing comorbidities in COPD.
Int J Chron Obstruct Pulmon Dis. 2015 Jan 7; 10: 95-109.

7. Hussell T, Lui S, Jagger C, Morgan D, Brand $\mathrm{O}$. The consequence of matrix dysfunction on lung immunity and the microbiome in COPD. Eur Respir Rev. 2018 Jun 27;27(148).

8. Avdeev SN. Antibacterial therapy in acute exacerbation of chronic obstructive lung disease. Pulmonology 2010; (2): 96-106 (in Russian).

9. The order № 535 of the MOH of the USSR of 22 April 1985. On the unification of microbiological (bacteriological) research methods used in clinical diagnostic laboratories of medical and preventive institutions.

\section{How to cite this article:}

Vasily D. Fedotov, Natalya V. Mokeeva, Irina S. Dobrotina, Anastasia N. Novikova, Viktoria E. Kovalenko and Aleksandra A. Kalınına. 2018. Peculiarities of Sputum Microbiocenosis among Occupational COPD Patients with Different Clinical Phenotypes and Comorbidities. Int.J.Curr.Microbiol.App.Sci. 7(12): 3203-3208. doi: https://doi.org/10.20546/ijcmas.2018.712.370 